\title{
The Nineteenth Century American Fiction: Hawthorne, The House of the Seven Gables and Its Reception: A Brief Overview
}

\author{
Saša Simović, Marija Mijušković \\ University of Montenegro
}

\begin{abstract}
Critics have always been interested in Nathaniel Hawthorne's literary oeuvre but that interest has varied over different periods of time. Nevertheless, we can claim that his books have always enjoyed a rousing reception. This paper discusses Nathaniel Hawthorne's famous romance The House of the Seven Gables and its reception from the time of its publication, 1851, to the present day. We will focus our attention on the essential features of the book that were commented on and reviewed by the most influential critics who dealt with Hawthorne's text.
\end{abstract}

Key words: The House of the Seven Gables, romance, review, reception, critic.

\section{Introduction}

Inspired by the great success of his master-piece The Scarlet Letter in 1850, Nathaniel Hawthorne began to work on another book in the late spring of the same year. He wrote The House of the Seven Gables in Lenox, West Massachusetts, where he lived for about a year after he had left Salem. Although he thought that the writing process would be completed by November, the book was finished on 26 January 1851. Publishers Ticknor, Reed and Fields published The House of the Seven Gables on 9 April 1851 (Rosenthal 1995:1). Hawthorne had on his mind several versions for the title of his romance - "The Seven Gables", "Maule's Well" (with the subtitle "The House of the Seven Gables"). However, his final choice seems to be the most appropriate one given the book's plotline as well as the symbolic perspectives of the house. 
In none of his romances is the burden of the past which "endangers" the present day represented in such a striking way as it is in The House of the Seven Gables. Therefore the reader is not surprised by a frequent use of terms such as "ancient", "antique", "hereditary", "ancestor" or "posterity". The plot of the romance implies interrelations between the generations of the families involved which proves to be an exceptionally functional device used by the author to "evoke" almost "forgotten" deeds and people from the past and place them in a contemporary sequence of events. In The House of the Seven Gables Hawthorne depicts a much simpler way of life compared to his previous romance. However, in both romances he uses the same narrative technique - mentioning, but not describing, the crucial point in the plot after which the whole story would unfold. In The Scarlet Letter Hawthorne depicts the consequences of Hester Prynne's "sin" and moral downfall but not the act of adultery itself. In The House of the Seven Gables he presents the consequences of Colonel Pyncheon's seizure of Maule's land over a long period of time but not the seizure itself. The consequences of Pyncheon's mighty decision would be felt by seven generations. Hawthorne manages successfully to present the incessant conflicts between the Pyncheons and Maules which are always somehow renewed and repeated. The problem of cyclic movement (Waggoner 1955) Hawthorne masterfully transfers to another perspective - the description of nature, primarily the elm, which with its luxuriant crown and green leaves rises over the house thus making it an inseparable part of landscape.

The major symbol in the romance proves to be the Pyncheon house, the embodiment of the once esteemed and well-to-do family, which is "forced" to cope with the cruelty and unpredictability of the present. The house has been "cursed" as Matthew Maule's words "God will give him blood to drink!" (Hawthorne in Merrill 1966:5) incessantly reverberate from the past. Old Matthew Maule was convicted and executed because of being an alleged wizard. Consequently, his land became easy prey for the haughty Colonel Pyncheon. Although there was no written document preserved, the narrator claims, there was obviously a dispute in the past between Maule, who defended what belonged rightfully to him, "the site [that] had become desirable in the eyes of a prominent and powerful personage", and the mighty Pyncheon, the claimant "characterized by an iron energy of purpose" (Hawthorne in Merrill 
1966:3). After Maule's death, the Pyncheon house was erected "over an unquiet grave", although many people expressed disapproval since

"[h] is house would include the home of the dead and buried wizard, and would thus afford the ghost of the latter a kind of privilege to haunt its new apartment, and the chambers into which future bridegrooms were to lead their brides, and where children of the Pyncheon blood were to be born."

(Hawthorne in Merrill 1966:5).

The entire plot of the book takes place in the Pyncheon mansion with the exception of the chapter "The Flight of Two Owls" which describes the running away of the Pyncheon siblings, Hepzibah and Clifford, into an unknown, (un)friendly world. Hawthorne masterfully uses the introductory paragraph in order to create "the stage" on which the whole story would be "performed":

"Half way down a by-street of one of our New England towns stands a rusty wooden house, with seven acutely peaked gables, facing towards various points of the compass, and a huge, clustered chimney in the midst. The street is Pyncheon Street; the house is the old Pyncheon House; and an elm-tree, of wide circumference, rooted before the door, is familiar to every townborn child by the title of the Pyncheon Elm. On my occasional visits to the town aforesaid, I seldom failed to turn down Pyncheon Street, for the sake of passing through the shadow of these two antiquities, - the great elm-tree and the weather-beaten edifice."

(Hawthorne in Merrill 1966:1)

The Pyncheon house, the book's eponymous house of the seven gables, used to be a grand, magnificent building. Now, it seems to be just a pale remnant of once immense wealth, potency and authority. Its interior is occasionally lit with sunshine, laughter seldom echoes through its halls and chambers. The narrator tells us that the old Pyncheon house always reminded him of a human countenance and the traces of bygone days were remarkably visible. However, 
the splendour of the house, which was remarkably evident in days of yore when Colonel Pyncheon built the mansion on Maule's restless grave, over time was lost. Maule's "curse" proved to "come true" on the day of the ceremony of consecration since Colonel Pyncheon was found dead in his oak chair drenched in his own blood.

The house of the seven gables symbolises the disintegration and decadence of the Pyncheon family. Instead of living in prosperity, with many descendants, it seems that the family regresses and becomes almost obsolescent.

The street in which it upreared its venerable peaks has long ceased to be a fashionable quarter of the town; so that, though the old edifice was surrounded by habitations of modern date, they were mostly small, built entirely of wood, and typical of the most plodding uniformity of common life. [...] But as for the old structure of our story, its white-oak frame, and its boards, shingles, and crumbling plaster, and even the huge, clustered chimney in the midst, seemed to constitute only the least and meanest part of its reality. So much of mankind's varied experience had passed there, - so much had been suffered, and something, too, enjoyed, - that the very timbers were oozy, as with the moisture of a heart. It was itself like a great human heart, with a life of its own, and full of rich and somber reminiscences.

(Hawthorne in Merrill 1966:26-27)

The disintegration of the Pyncheons is masterfully presented through the characters of the siblings, Hepzibah and Clifford. For the old maiden Hepzibah, the house is her family legacy, she seems to be "destined" to the loneliness and darkness of its chambers which used to be filled with life and vigour. The Pyncheon house is her home but it is a home without warmth and joy. Hepzibah faces an unfavourable financial situation and therefore decides to run a shop. This shop for her is just another sign of degradation, necessary in order to sustain her small family. 
A lady - who had fed herself from childhood with the shadowy food of aristocratic reminiscences, and whose religion it was that a lady's hand soils itself irremediably by doing aught for bread this born lady, after sixty years of narrowing means, is fain to step down from her pedestal of imaginary rank. Poverty, treading closely at her heels for a lifetime, has come up with her at last. She must earn her own food, or starve! And we have stolen upon Miss Hepzibah Pyncheon, too irreverently, at the instant of time when the patrician lady is to be transformed into the plebeian woman.

(Hawthorne in Merrill 1966:40)

For Clifford, the house of the seven gables seems not to be of crucial importance. At least not of the significance it could have had if only he had not been forced to pay for somebody else's "sins" and spend most of his life in prison, convicted for a crime he did not commit. The only joy in this world that he is able to perceive is embodied in his young cousin Phoebe.

Maule's well represents the union of the past and present as well as that of the two families. According to some superstitious stories its water is enchanted and forebears the stain of the old days and the curse of Matthew Maule. That is why Holgrave warns Phoebe against drinking the water with "magical" power, stating the following: "Be careful not to drink at Maule's well![...] Neither drink nor bathe your face in it![...] because, like an old lady's cup, it is water bewitched!" (Hawthorne in Merrill 1966:105-106).

The decadence of the family is masterfully presented through the "great similarity" between the Pyncheon siblings and the Pyncheon hens. With a dose of humour the narrator states that these hens, since they were of the "aristocratic line", could not "understand" the simple language of the ordinary village hens, in almost the same way that the "patrician" Pyncheons had nothing in common with "plebeians". The decline and waning of the mighty Pyncheons is remarkably presented in the following extract:

Nor must we forget to mention a hen-coop of very reverend antiquity that stood in the farther corner of the garden, not a great way from the fountain. It now contained only Chanticleer, his two 
wives, and a solitary chicken. All of them were pure specimens of a breed which had been transmitted down as an heirloom in the Pyncheon family, and were said, while in their prime, to have attained almost the size of turkeys, and, on the score of delicate flesh, to be fit for a prince's table. In proof of the authenticity of this legendary renown, Hepzibah could have exhibited the shell of a great egg, which an ostrich need hardly have been ashamed of. Be that as it might, the hens were now scarcely larger than pigeons, and had a queer, rusty, withered aspect, and a gouty kind of movement, and a sleepy and melancholy tone throughout all the variations of their clucking and cackling. It was evident that the race had degenerated, like many a noble race besides, in consequences of too strict a watchfulness to keep it pure. These feathered people had existed too long in their distinct variety. [...] The distinguishing mark of the hens was a crest of lamentably scanty growth, in these latter days, but so oddly and wickedly analogous to Hepzibah's turban, that Phoebe [...] was led to fancy a general resemblance betwixt these forlorn bipeds and her respectable relative.

(Hawthorne in Merrill 1966:98-99)

Focusing his attention on this interesting breed of "feathered people" and its indisputably "aristocratic origin", the reader can recognise a direct allusion to Clifford and Hepzibah. Through this, we find out that the rooster and his two hens became a little bit "cracked" because of their solitude and being cut off from the rest of the world. The ex-prisoner Clifford could not watch them living in an enclosed space. Consequently, "they had been set at liberty, and now roamed at will about the garden" (Hawthorne in Merrill 1966:168).

The symbolism of the weeds in this romance is noteworthy as well. Weeds that grow in the family garden are named the "evil" of the by-gone days, "symbolic of the transmitted vices of society". They incessantly appear and reappear thus showing that the huge family burden is passed from one generation to the next. But the "evil" which broods over the Pyncheons and which is embodied in the weeds is not destined to spread throughout. A Maule, 
the descendant of Matthew Maule, does not allow it. The Maules, victims of the overbearing nature and pride of the once mighty Pyncheons, succeed in reducing the "evil" whose seed had been planted a long time ago. Therefore, not everything is lost. This will be proved by the young cousin, Phoebe Pyncheon, who brings "sunshine" into the story. The present relations between the Pyncheons and Maules are strikingly different from the relations between their ancestors, which is shown through the relationship of Phoebe and the daguerreotypist Holgrave, the youngest offspring of the families. It is through their union that Hawthorne bathes the conclusion of the book in sunlight. This proves to be significantly different from the conclusion of his previous romance, his master-piece, The Scarlet Letter.

\section{The House of the Seven Gables and Its Reception}

It is highly possible that Hawthorne drew his inspiration for the major symbol, the house of the seven gables, from his boyhood when he was fascinated by the ancient mansion which "in the midst of a beautiful garden, stands facing the blue waters of the harbor at the foot of Turner Street in Salem, Massachusetts" (Merrill 1966:xvi). Historians discovered that in 1668 a certain John Turner bought the land on which he built a house which consisted of four rooms. As the family grew over time, the house underwent significant architectural changes and was enlarged several times until seven gables were created. His grandson sold the house in 1782 to Captain Samuel Ingersoll whose wife proved to be Nathaniel Hawthorne's aunt. (Merrill 1966:xvi). For a long period of time the young Hawthorne paid visits to his cousin, Miss Susie Ingersoll, who told him interesting stories about the history of the house. "A chair is now shown to visitors as the Hawthorne chair, said to have been the favourite of the young writer in many his visits. Small wonder that the house took on a living interest to him, and that the children of his brain moved through its rooms as to the manor born" (Merrill 1966:xvi-xvii).

Seriously concerned about the possibility that the new romance would contain "too much of darkness" as was the case with The Scarlet Letter in which he masterfully presented the story of "sin", adultery and moral downfall within the framework of the seventeenth century Puritan Boston, this time the author "permitted" more rays of sunlight to pour over the pages of The House of 
the Seven Gables. In his letter of April 1851 the great American writer and Hawthorne's literary friend, Herman Melville, praised the book, stating that its contents did not belie its romantic title as well as that the book, for the pleasantness of the running interest, surpasses the author's previous literary achievements. Furthermore, Melville stated the following:

This book is like a fine old chamber, abundantly, but still judiciously, furnished with precisely that sort of furniture best fitted to furnish it. There are rich hangings, wherein are braided scenes from tragedies! There is old china with rare devices, set out on the carved buffet; there are long and indolent lounges to throw yourself upon; there is an admirable sideboard, plentifully stored with good viands; there is a smell as of old wine in the pantry; and finally, in one corner, there is a dark little black-letter volume in golden clasps, entitled 'Hawthorne: A Problem'. It has delighted us; it has piqued a re-perusal; it has robbed us of a day, and made us a present of a whole year of thoughtfulness; it has bred great exhilaration and exultation with the remembrance that the architect of the Gables resides only six miles off, and not three thousand miles away, in England, say.

(Melville in Rosenthal 1995:23)

Evert August Duyckinck in The Literary World (26 April 1851) states that if one wants to understand Hawthorne's book adequately, one has to be in the right mood, time and place when reading this text. According to this distinguished nineteenth century intellectual, The House of the Seven Gables is a book full of light and shade, "parts and diversities", without a peculiar richness in the style: "in some respects it is plain, but it flows on pellucid as a mountain rivulet", so that the reader can become aware of its refreshing purity. Duyckinck claims that the sun shines into the house primarily to expose the darkness. It is the house itself which proves to be the chief dramatis personae in the book since "it is alive and vital, albeit on a dusty antiquity" (Duyckinck in Rosenthal 1995:27). The story which is revealed in the book is actually "a tale of retribution, of expiation extending over a period of two hundred years" 
(Duyckinck in Rosenthal 1995:28). Duyckinck in his review emphasises the following as well:

You may read the book into the small hours beyond midnight, when no sound breaks the silence but the parting of an expiring ember, or the groan of restless mahogany, and you find that the candle burns a longer flame, and that the ghostly visions of the author's page take shape about you. Conscience sits supreme in her seat, the fountains of pity and terror are opened; you look into the depths of the soul, provoked at so painful a sight - but you are strengthened as you gaze; for of that pain comes peace at last, and these shadows you must master by virtuous magic. Nathaniel Hawthorne may be the Cornelius Agrippa to invoke them, but you are the mirror in which they are reflected.

(Duyckinck in Rosenthal 1995:28)

Rufus Wilmot Griswold in his review published in The International Magazine of Literature, Art and Science (May 1851) remarked that The House of the Seven Gables can be considered less original, less striking and less powerful than The Scarlet Letter. Nevertheless, he considers this book "the purest piece of imagination in [American] prose literature" (Griswold in Rosenthal 1995:31). In an anonymous review published in the Christian Examiner (May 1851) the author claims that this piece of writing of Hawthorne's indisputably presents a creation of great power, although inferior in interest to The Scarlet Letter.

The impression which it leaves on the reader's mind is, indeed, much pleasanter than that produced by its predecessor; but its plot is more complex, the characterization more exaggerated, and the artistic execution less perfect. Viewed as a whole, it will stand much higher than when considered in its separate parts; for the general outline is well conceived, but the filling up is not of equal excellence. There is too much of disquisition, and too little of narrative and dialogue. 
(Anonymous in Rosenthal 1995:32)

In his study Hawthorne (1879) Henry James states that The House of the Seven Gables is a rich, delightful work but not as shaped and fashioned as The Scarlet Letter. James claims that he always considered it much more functional as a prologue to a great novel than a great novel itself. The subject of the story, according to James, does not fill it out adequately. The characters in the book are rather to be considered figures, "they are all pictures rather than persons". He also claims that they are all types

to the author's mind, of something general, of something that is bound up with the history, at large, of families and individuals, and each of them is the centre of a cluster of those ingenious and meditative musings, rather melancholy, as a general thing, than joyous, which melt into the current and texture of the story and give it a kind moral richness.

(James in Rosenthal 1995:55)

Many twentieth century critics focused their attention on the structure of The House of the Seven Gables, especially the end of the book. F.O. Matthiessen in his influential study American Renaissance: Art and Expression in the Age of Emerson and Whitman (1941) claims that the conclusion of The House of the Seven Gables could satisfy only a few people. According to Matthiessen, the main theme which Hawthorne developed from the past of the Pyncheon and Maule families is the curse that the Pyncheons continued to bring upon themselves. Putting his characters

in a definite environment, he could not give the sense of their being in continuous contact with that larger outside world [...] Furthermore, when Hawthorne centers directly on the presentation of his individuals, he can ordinarily manage no more than to give a careful notation of their traits [...] instead of revealing them gradually through significant incidents. Even in their conflicts with 
one another, description nearly always usurps the place of immediate action.

(Matthiessen 1941:335)

Leland Schubert in his study Hawthorne, the Artist: Fine Art Devices (1944) comments on the specific use of colours, light, shadow and sound in Hawthorne's fiction. Discussing the dominant colours in The House of the Seven Gables Schubert emphasises "a dull yellow and green, almost brown" (Schubert 1944:101-102). Schubert claims that Hawthorne's auditory imagination "may have been weak or undeveloped" since he makes "much less use of sound than many writers do" (1944:112). According to this critic, Hawthorne "sees the sound" and often creates "sound images and sound patterns of considerable effectiveness" (1944:113). Schubert states that the sound of the shop bell could be considered "the audible expression of Seven Gables's moral" (1944:121). Yvor Winters in "Maule's Curse, or Hawthorne and the Problem of Allegory / Defense of Reason" (1947) points out that of Hawthorne's three long works The Scarlet Letter, The House of the Seven Gables and The Marble Faun, it is The Scarlet Letter that can be considered pure allegory while the other two are impure novels, "novels with unassimilated allegorical elements" (Winters in Kaul 1966:11). According to Winters, The Scarlet Letter is faultless in scheme and in detail. "The second and third are interesting, the third in particularly, but both are failures" (Winters in Kaul 1966:11).

Critical reviews published in 1950s and 1960s presented a significant step forward in the study of Hawthorne's fiction. Namely, Richard Harter Fogle in Hawthorne's Fiction: The Light and the Dark (1952) states that in Hawthorne's texts the reader can recognise elements of simplicity and complexity. Hawthorne's tone is calm and there is a specific combination of light and darkness. Commenting on the characterisation in this romance Fogle states that Phoebe is less sensitive than Clifford, and less intelligent than Holgrave but proves to possess greater strength than either of them. This critic also notes that equilibrium in Hawthorne's texts implies some kind of sacrifice - "the head and the heart can never be in a harmony and no character can be complete. Where the materials for synthesis, as in The House of the Seven Gables [...] we find 
only an unequal compromise" (Fogle 1969:221). Hyatt H. Waggoner in Hawthorne: A Critical Study (1955) points out that The House of the Seven Gables was written more carefully than The Scarlet Letter. Therefore, Waggoner claims, the book can be considered "the product in a much greater degree of conscious, even of self-conscious artistry" (1955:151). In his analysis of this romance Waggoner pays special attention to the house itself, which according to him represents a place of happening and a symbol.

Millicent Bell in her study Hawthorne's View of the Artist (1962) recognises in The House of the Seven Gables a large amount of symbolism specific to gothic novels. She also points out the fact that Hawthorne's fiction is "obsessed" with the theme of guilt. Terence Martin in his study Nathaniel Hawthorne published in 1965 emphasises that no American writer before Hawthorne tried to present in such a unique way the past and the present. $\mathrm{He}$ agrees with Henry James that the original idea does not fulfill the story. Discussing the characterisation in The House of the Seven Gables he points out the young Phoebe who has the responsibility of redemption on her shoulders. "He [Hawthorne] emphasizes her ability to make any place look like a home, from a hut in the forest to the house she has come to live in" (Martin 1983:133). In Hawthorne's Images: The "Proper Light and Shadow" in the Major Romances Richard Harter Fogle (1969) points out that we should never study Hawthorne's characters separately since, taken out of a context, they look incomplete and unsatisfying. There is no dominant hero or heroine in Hawthorne's fiction, claims Fogle. The main characters "exist" in a group. According to Fogle, Hawthorne's universe has its own solar system and the sun "is its center, the divine light and the source of light" (Fogle 1969:49). Frederick Crews in his seminal study The Sins of the Fathers: Hawthorne's Psychological Themes (1966) claims that in The House of the Seven Gables the reader can recognise "the risks" of artistic imagination, being "obsessed" with unconscious desires. The conclusion of this romance, according to Crews, was psychologically necessary. Furthermore, he claims that it is imperfect repression which could be understood as the agent of all the ironic justice in this book (Crews 1966:178-179).

Richard H. Brodhead in Hawthorne, Melville and the Novel (1976) states that Hawthorne in The House of the Seven Gables abandons the grandness of 
tragedy in order to "apply" ordinary life. Brodhead highlights the specific modulation between the mimetic and symbolic in the book. George Dekker in The American Historical Romance (1987) states that Hawthorne could be called a historical ironist who recognised the excesses of the Puritans as well as weaknesses and faults of his own political party. Dekker points out that, in this romance, Hawthorne joins "Cooper, Emerson, Mark Twain, and many other nineteenth-century critics in finding Scott and his fictions deeply subversive of American political and social ideals (Dekker 1987:341). In a highly complex and inspirational study The Anatomy of National Fantasy: Hawthorne, Utopia and Everyday Life (1991), Lauren Berlant explores the problem of national identity in Hawthorne's texts. Discussing a female-popular private source of national narrative Berlant claims that it proves to be central in The House of the Seven Gables. "It is, and is not, necessary for the maintenance of patriarchal law; it is, and is not, an instance of autonomous female political theory. But as the guardian of desire and hope for future justice, the domesticated institution of women's consciousness is crucial to Hawthorne's critical revision of American national identity" (Berlant 1991:157). Samuel Chase Coale, in Mesmerism and Hawthorne (1998), claims that the aforementioned romance, "saturated with mesmeric themes and powers, confronts all the aspects of mesmerism both in the text itself and in the very nature of that text" (Coale 1998:91). Coale also discusses the great "frenzy" which ruled ante-bellum America. The Pyncheons can control and rule the world of riches and social status, but the Maules rule the mysterious world of dreams, hypnosis and mesmeric powers. In this romance "Hawthorne creates dreamscapes, the mysterious places where mesmeric trances take us" (Coale 1998:95). Allan Lloyd-Smith in his essay "Nineteenth Century American Gothic" points out that Nathaniel Hawthorne adopted the tone of comic Gothic in The House of the Seven Gables. In the very house, "erected on a shameful rotting corpse", and whose occupants were frequently "the victim of Maule's curse" the reader can recognise "a version of the Gothic haunted castle, brought up to date and containing a cent shop selling miscellaneous items" (Lloyd-Smith in Punter 2008:116). In her article "Comical Reflections and Delayed Affect in The House of the Seven Gables" published in the Nathaniel Hawthorne Review (2015), Julie Wilhelm deals primarily with Hawthorne's complex relationship to sentimentalism. Wilhelm claims that 
although Hawthorne was determined to distinguish himself from the " $\mathrm{d}-\mathrm{d}$ mob of scribbling women" or "commercially successful sentimental women writers", insisting that his texts reveal "hard truths rather than sentiment and sales", it can be "proved" that the writer, "keen to support his family and build his reputation, cared deeply about writing novels that the public would buy" (Wilhelm 2015:112).

The number, quality and variety of critical reviews of Hawthorne's romances, notably of The House of the Seven Gables, which have been published since the mid-nineteenth century, highlight the author's artistic uniqueness as well as the great complexity of his style. Some of these reviews are of crucial importance for the study and proper understanding of Hawthorne's texts. Critics have focused their attention on various literary and theoretical issues ranging from the use of colours, the distinction of light and darkness, sound images to allegory, symbolism, originality and characterisation. In this paper we have tried to shine additional light on the romance and its reception through different periods of time as well as to point out some of the book's distinctive features that have been discussed by the most influential critics.

\section{References:}

1. Barry, P. (2002) Beginning Theory: An Introduction to Literary and Cultural Theory. Manchester and New York: Manchester University Press.

2. Bercovitch, S. and Jehlen, M. (eds) (2004) Ideology and Classic American Literature. Cambridge, New York: CUP.

3. Bell, M. (1962) Hawthorne's View of the Artist. New York: University Publishers.

4. Berlant, L. (1991) The Anatomy of National Fantasy: Hawthorne, Utopia and Everyday Life. Chicago and London: The University of Chicago Press.

5. Brodhead, R.H. (1976) Hawthorne, Melville and the Novel. Chicago: The University of Chicago Press.

6. Coale, C.S. (1998) Mesmerism and Hawthorne: Mediums of American Romance. Tuscaloosa and London: The University of Alabama Press. 
7. Crews, F. (1989) The Sins of the Fathers: Hawthorne's Psychological Themes. Revised edition. Berkley, Los Angeles, London: University of Carolina Press.

8. Dekker, G. (1990) The American Historical Romance. Cambridge, New York: CUP.

9. Fogle, R.H. (1969) Hawthorne's Fiction: The Light and the Dark. Revised edition. Norman: University of Oklahoma Press.

10.Fogle, R.H. (1969) Hawthorne's Imagery: The "Proper Light and Shadow" in the Major Romances. Norman: University of Oklahoma Press.

11.Hawthorne, N. (1966) The House of the Seven Gables. Atlanta, Belmont, Calif, Dallas: Allyn and Bacon, Inc.

12.Kaul, A.N. (ed.) (1966) Hawthorne: A Collection of Critical Essays. Englewood Cliffs, New Jersey: Prentice Hall Inc.

13.Matthiessen, F.O. (1968) American Renaissance: Art and Expression in the Age of Emerson and Whitman. New York: OUP.

14.Reynolds, L.J. (ed.) (2001) A Historical Guide to Nathaniel Hawthorne. Oxford, New York.: OUP.

15.Rosenthal, B. (ed.) (1995) Critical Essays on Hawthorne's The House of the Seven Gables. New York: G.K. Hall \& Co.

16.Schubert, L.(1944) Hawthorne, the Artist: Fine - Art Devices in Fiction. Chapel Hill: The University of North Carolina Press.

17.Terence, M. (1983) Nathaniel Hawthorne. Revised edition. New York: Twayne Publishers.

18.Vukčević, R. (2002) Reading American Literature: A Critical Anthology. Podgorica: Univerzitet Crne Gore, Institut za strane jezike.

19.Vukčević, R. (2005) A History of American Literature: Then and Now. Podgorica: Univerzitet Crne Gore, Institut za strane jezike.

20.Waggoner, H.H. (1955) Hawthorne: A Critical Study. Cambridge: The Belknap Press.

21.Wilhelm, J. (2015) Comical Reflections and Delayed Affect in "The House of the Seven Gables". // Nathaniel Hawthorne Review. / Ed. by J.E. Hall. Vol. 41, N. 2. The Nathaniel Hawthorne Society. 


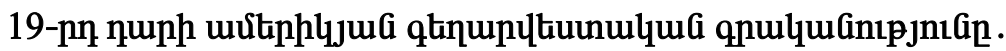

\section{<npnnai 3np uquunnthwaGipny unnian}

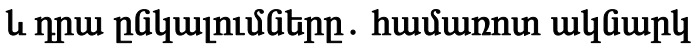

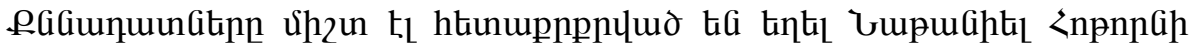

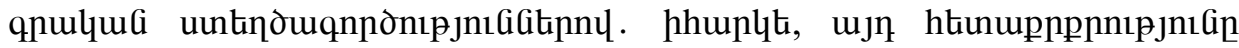

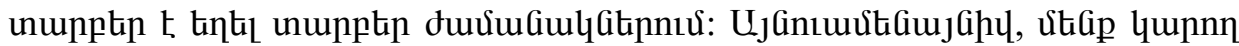

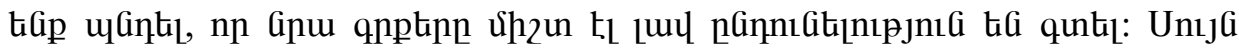

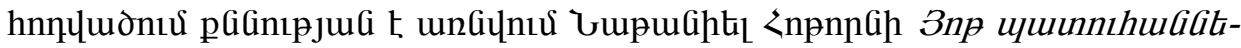

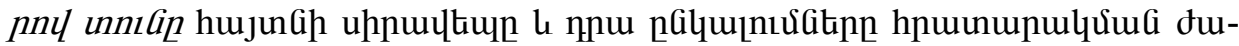

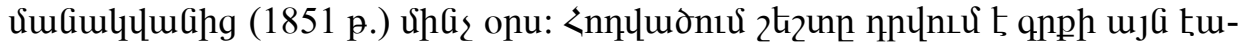

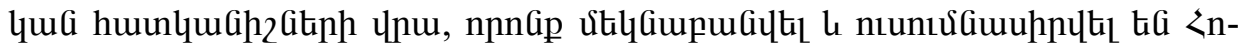

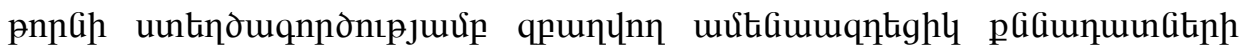
4nnưhg: 